\title{
Sustainability and Triple Bottom-Line Performance in the Horticulture Supply Chains in Nairobi, Kenya
}

\author{
Muruli Cetric Mukatia, Wainaina Githii, Ogoro Thomas Ombati \\ Department of Management Science, School of Business, University of Nairobi, Nairobi, Kenya \\ Email: cetric.muruli12@gmail.com,wainaina.githii@uonbi.ac.ke, thomasombati@uonbi.ac.ke
}

How to cite this paper: Mukatia, M.C., Githii, W. and Ombati, O.T. (2018) Sustainability and Triple Bottom-Line Performance in the Horticulture Supply Chains in Nairobi, Kenya. American Journal of Industrial and Business Management, 8 , 1389-1406.

https://doi.org/10.4236/ajibm.2018.85093

Received: March 25, 2018

Accepted: May 28, 2018

Published: May 31, 2018

Copyright $\odot 2018$ by authors and Scientific Research Publishing Inc. This work is licensed under the Creative Commons Attribution International License (CC BY 4.0).

http://creativecommons.org/licenses/by/4.0/

c. (i) Open Access

\begin{abstract}
The purpose of this study is to establish the relationship between Sustainability and TBL Performance in Horticulture Sector in Kenya. The study adopts a descriptive research design. A census of all the 25 registered horticulture firms within Nairobi and its environs was conducted. The majority of horticulture firms in Nairobi and its environs have adopted the TBL dimensions to a large extent. The authors faced the challenge of lack of co-operation from the respondents either by failing to receive back the questionnaires or complete refusal to give the authors audience to present their case. The majority of the horticulture firms are fully aware of the benefits of adopting TBL dimensions and firms that have already embraced the three dimensions, have in mind of the relationship between sustainability and TBL performance.
\end{abstract}

\section{Keywords}

Triple Bottom-Line (TBL), Supply Chains, Sustainability, Performance, Horticulture, Sector, Kenya

\section{Introduction}

The focus on business sustainability rather than generic aspects of sustainability has attracted more attention to sustainability in all sectors including food and horticulture. Unlike other industries, food sector has received more public attention in regard to sustainability [1]. Supply chain management vulnerabilities expose food to quality-based issues [2]. This led to increased food costs [3]. Sustainability issues are complex by nature [4]. Business sustainability is the increase in productivity and/or reduction of consumed resources without compromising product or service quality, competitiveness, or profitability while 
helping to save the environment [5]. Food industry is confronted with issues ranging from migrant worker abuses, product safety and animal handling practices to the environmental impacts of soil erosion, habitat destruction, fertilizer run-offs and use of herbicides and pesticides [1].

The concept of Triple Bottom Line was coined by John Elkington in 1998. TBL focuses on three dimensions of an organization's operations. These dimensions include economic or financial, social and the environmental. Due to the increase of global awareness of environmental challenges, consumers have become more concerned about promotion of green designs [2] [6]. Thus, consumers have become more aware of the consequences of their consumption decisions and their choices are increasingly affecting the product offerings [7].

In Sustainable Supply Chain Management (SSCM) literature, the inclusion of sustainability into the theory of Supply Chain Management (SCM) is most often based on the TBL approach [8]. SSCM refers to the management of material, information and capital flows as well as cooperation among companies along the supply chain while considering the three dimensions of sustainability [9].

Horticulture sector is an important sector in Kenyan economy. Issues of sustainability especially in the flower farming have remained a big concern to the policy makers, stakeholders and the Horticultural Crops Development Authority (HCDA). According to HCDA, work environment, water usage, environmental issues i.e. chemicals used on the flower farms, and employee wages are key concerns. All these issues can be well addressed if organizations adopt the environmental, social and economic aspects of TBL into their supply chains [1].

A number of studies have been carried out on sustainability and Triple Bottom Line approach in organizational supply chains. Situational variables and sustainability in multi-attribute decision making established that the environmental dimension of sustainability is the most influential followed by economic and social [10]. A study on crippled bottom line-measuring and managing sustainability concluded that the relative indicators with focus on people utility compared to planet and people harm seem to be relevant for measuring the level of sustainability [11].

It was evident from the above studies that there was lack of research on the topic of sustainability of horticulture sector supply chains in Kenya. The authors aimed to narrow the research gap by focusing on the horticulture sector and specifically studying sustainability and TBL performance from a supply chain perspective. The study questions included: To what extent are the TBL dimensions adopted in horticulture sector in Kenya? What are the triggers or drivers of sustainability in the horticulture sector in Kenya? What is the relationship between SSCM and TBL performance in horticulture sector in Kenya?

This study is will be useful to policy makers in specific to the government, government agencies and various stakeholders in the agricultural sector as they use the findings and recommendations of the study to improve food security in the country by applying sustainability and Triple Bottom-Line concept in farming practices as well as managing efficient and effective food supply chain. Pro- 
fessionals and academicians are also in a position to clearly understand major practical challenges which need to be addressed.

\subsection{Literature Review}

Organizations operate within a wider environment that is composed of a number of variables that include political, economic, socio-cultural, technological, ecological and legal. Any change in any one of these variables is expected to have far reaching implications in the way organizations operate. This compels organizations to adopt SSCM practices in addressing any change that may occur in any of the variables. The goals of businesses are achieved through the application of change management approaches including SSCM [12].

Supply Chain Management (SCM) is an important environmental and social subject relating to corporate sustainability [13]. Companies' interest in SCM has increased in recent decades because of growing global competition, outsourcing of companies' non-core activities and the shortening of product life cycles [14]. Companies have become more deeply committed to corporate social responsibility (CSR) and sustainability by refusing to implement a reductionist corporate management model focused only on shareholders' interests [15]. Under this scenario, sustainable management of supply chains has become a core strategic factor for companies worldwide. SSCM is defined as reformist SCM "which manages the material, information and capital flows as well as cooperation among companies along the supply chain while taking goals from all three dimensions of sustainable development, i.e. economic, environmental and social, into account which are derived from customer and stakeholder requirements" [9].

The holistic view on sustainable supply chain management (SSCM) covers environmental, economic and social aspects. SSCM as strategic, transparent integration and achievement of an organization's social, environmental, and economic goals in the systemic coordination of key interorganizational business processes for improving the long-term economic performance of the individual company and its supply chains [16]. SSCM relates to the long-term improvement of organizations and has implications for companies' economic bottom lines [17]. The concept of SSCM is considered across the entire supply chain; the upstream, the focal organization and the downstream supply chain. In the upstream, the suppliers are considered while in the downstream the consumers and ultimately its disposal are taken in consideration. Environmental and social issues do not only affect the focal organization, but also other stakeholders across the entire supply chain. The organizations need sustainability not just for the sake of practicing but because it is a primary management principle that needs to be observed [18]. At the intersection of the three dimensions of the TBL is the core of sustainability and there are a number of activities that not only positively affect the environment and immediate society but also have positive economic implications on the organization. 
There is a direct relationship between sustainability and TBL performance outcomes of the organizations [19]. The application of Elkington's TBL in SC is meant to ensure that organizations operate sustainable supply chains [16]. The aim of TBL is not to suggest that firms should identify and engage in social and environmental activities not likely to harm economic performance but instead it guides managers to identify activities which improve economic performance and dictates the avoidance of social and environmental activities that lie outside of the intersection [16]. The application of TBL in supply chain is meant to ensure that organizations operate sustainable supply chains. Horticulture sector being a very important sector in any economy in the world, it is therefore of essence that the sector to be self sustaining by adopting all the three dimensions of the TBL concept.

From the above literature review and studies, it was evident that there existed little on the TBL and most importantly none of existing study on Sustainability and TBL Performance in Food sector with specific interest of Horticulture. Figure 1 presents the proposed conceptual framework.

The study adopted a descriptive design to all the 25 registered horticultural firms in Nairobi. The data was collected by use of questionnaires that were administered by drop and pick method. The questionnaires contained four sections (1, 2, $3 \& 4)$. Section 1 sought data on firm profile, Section 2 had questions on environmental, social and economic variables, Section 3 sought data on the triggers/drivers of Sustainability in Horticulture Sector; and Section 4 contained questions on the relationship between SSCM Practices and TBL Performance. Two respondents were considered from each firm to participate in the study. The author was interested in the supply chain managers or its equivalent as the respondents from the twenty-five horticultural firms.

The data was sorted and coded accordingly to allow more appropriate analysis to be carried out. Frequencies were used to show both the firm profile and the extent to which horticultural firms have adopted TBL concept and sustainability of supply chain; factor analysis was used for triggers/drivers of sustainability and regression analysis was applied to explain the relationship between TBL and performance outcomes. Tables and histograms were also used to enhance output presentation. The following model was used to show the relationship between sustainable supply chain management practices and TBL performance:

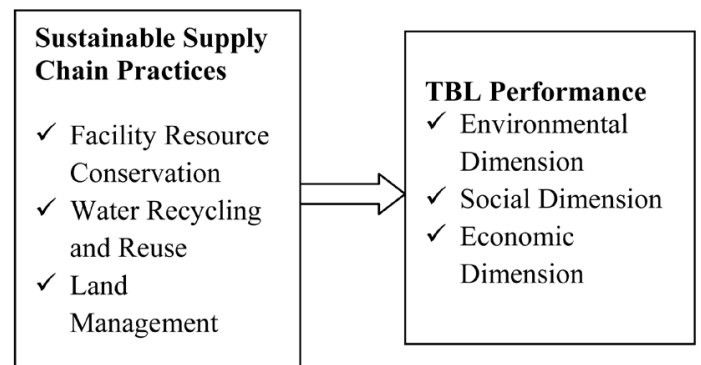

Figure 1. Proposed conceptual framework. Source: Developed from Pullman, M., Maloni, M.J., and Carter, C., (2009). 


$$
y=\beta_{0}+\beta_{1} X_{1}+\beta_{2} X_{2}+\beta_{3} X_{3}+\beta_{4} X_{4}+e
$$

where: $y=$ TBL Performance (Environmental Dimension, Economic Dimension and Social Dimension), $\beta_{0}=$ Constant Term, $\beta_{1}=$ Beta coefficients, $X_{1}=$ Facility resource conservation, $X_{2}=$ Water recycling and reuse, $X_{3}=$ Land management and $X_{4}=$ Social sustainability practices.

The authors successfully collected back 37 out of 50 questionnaires from the respondents thus representing a response rate of $74 \%$. The firms' profile was sought from the respondents and the data analyzed using descriptive statistics.

The authors sought information of the ownership of the horticultural firms in Nairobi area and its environments and the responses showed that $75.7 \%$ are locally owned while only $24.3 \%$ of the firms are foreign owned. It was also noted that most of the firms were not too old as it is depicted by the number of years the firm has been in operation which, majority registered $54.1 \%$ being below 10 years in operation and only $45.9 \%$ having operated in Nairobi Kenya for years spanning between 10 - 20 years. $86.5 \%$ of firms have employees of above 50 thus this confirms the need for sustainability and triple bottom-line.

The authors sought to know the extent to which horticultural firms have adopted environmental aspect of TBL dimension. Questions revolving on the environmental issues were then asked to the respondents of which they rated the statements on likert scale of 1 to 5 i.e. 1-not at all and 5-to a very large extent. The results indicate the environmental factors and their corresponding statistics where most horticultural firms practice and take some environmental issues more seriously than others. The firms having clearly stated environmental objectives and plans, use of pesticides that are not harmful to the environment, and the use of environmentally friendly cleaning materials are the most valued factors highest mean of $4.76,4.65$ and 4.43 respectively.

On Social Sustainability, from the results it is evident that most companies have realized the benefits that accrue on the social dimension aspect.

Corporate social responsibility, Job satisfaction of workers, Attainment of worker quality of life and Facilitation of worker skill development are the most key concerns of the horticulture firms as shown by means of 4.67, 4.51, 4.27 and 4.11 respectively. Most companies have realized the benefits that accrue on the social dimension aspect. It is also clear that economic factors are still key concern to the management as it manifests itself by the highest means scored. Cost savings, maximization of shareholders' wealth and profit maximization, use of sustainable sources of energy such as solar and wind, minimum packaging materials on products to preserve the natural resources, and use of sustainable sources of raw materials are some of the interventions that work favorably to most horticultural firms.

The authors also sought to know if the economic factors are considered more to the expense of the environmental and social dimensions. From the results, it is clear that economic factors are a still key concern to the management. Cost savings, maximization of shareholders' wealth and profit maximization, use of 
sustainable sources of energy such as solar and wind, minimum packaging materials on products to preserve the natural resources, and use of sustainable sources of raw materials are some of the interventions that work favorably to most horticultural firms.

Among the factors that contribute to the social and environmental dimensions is the positions created that relates to the same with the sole purpose of advocating and advancing the agendas that relate to their portfolios. The authors sought to understand the existence of various positions apart from the Supply Chain Manager and Operations Manager in the horticulture firms.

The results show that there is a corporate environmental policy in place as is shown by $97.3 \%$, a clear indication the steps that majority of the horticulture firms are taking towards environmental dimension. The management does realize the importance of the dimension and the long-term benefits that come along with being environmental conscious. There is also a clear indication that most firms have established environmental board of directors, a position of environmental manager and a position of corporate social responsibility manager as shown by $89.2 \%, 75.7 \%$ and $78.4 \%$ respectively. Consequently, there are some firms which have not realized the importance of environmental and social dimensions and therefore having not seen the reason to have a position of environmental manager and corporate social responsibility manager as shown by $24.3 \%$ and $21.6 \%$ respectively.

\subsection{Sustainable Supply Chain Practices and TBL Performance}

Relationship between SSC Practices and performance of horticulture firms was of importance to the authors and therefore three regression analysis was run; for environmental, social and economic dimensions.

A multivariate regression model was applied where the regression model specifically connects the average values of $y$ for various values of the $x$-variables. The regression model used is as follows:

$$
y=\beta_{0}+\beta_{1} X_{1}+\beta_{2} X_{2}+\beta_{3} X_{3}+\beta_{4} X_{4}+e
$$

where:

$$
\begin{aligned}
& y=\text { TBL performance; } \\
& \beta_{0}=\text { Constant term; } \\
& \beta_{1}=\text { Beta coefficients; } \\
& X_{1}=\text { Facility resource conservation; } \\
& X_{2}=\text { Water recycling and reuse; } \\
& X_{3}=\text { Land management; } \\
& X_{4}=\text { Social sustainability practices. }
\end{aligned}
$$

\subsection{Sustainable Supply Chain Practices and Environmental Dimension}

The model summary is presented in Table 1 . The model has an $\mathrm{R}$ square value of 0.950 indicating that the percentage of the dependent variable variance that 
Table 1. Regression model summary.

\begin{tabular}{ccccccccccc}
\hline \multirow{2}{*}{ Model } & \multirow{2}{*}{$\mathrm{R}$} & \multirow{2}{*}{ R Square } & \multirow{2}{*}{$\begin{array}{c}\text { Adjusted } \\
\text { R Square }\end{array}$} & \multirow{2}{*}{$\begin{array}{c}\text { Std. Error } \\
\text { of the Estimate }\end{array}$} & \multicolumn{5}{c}{ Change Statistics } \\
\cline { 6 - 9 } & & & R Square Change & F Change & df1 & df2 & Sig. F Change \\
\hline 1 & $0.975^{\mathrm{a}}$ & 0.950 & 0.944 & $3.564479690827230 \mathrm{E} 0$ & 0.950 & 153.212 & 14 & 113 & 0.000 & 2.131 \\
\hline
\end{tabular}

a. Predictors: (Constant), Facility resource conservation, water recycling and reuse, land management and social sustainability practices; b. Dependent Variable: Environmental dimension. Source: (Research Data, 2015).

is explained by the independent variables is $95 \%$. The $\mathrm{P}$-value of 0.000 which is less than 0.05 implies that the model of environmental dimensional is significant at the 5 per cent significance. $\mathrm{R}$ is the correlation coefficient which shows the relationship between the study variables, from the findings shown in the table below there is a strong positive relationship between the study variables as shown by 0.975 . Durbin-Watson is the number that tests for autocorrelation in the residuals from a statistical regression analysis. The Durbin-Watson statistic is always between 0 and 4 . A value of 2 means that there is no autocorrelation in the sample. Values approaching 0 indicate positive autocorrelation and values toward 4 indicate negative autocorrelation. The findings show that Durbin-Watson value is 2.131 hence no autocorrelation in the sample.

ANOVA findings (P-value of 0.00 ) in Table 2 show that there is correlation between the predictor's variables and response variable. An F ratio is calculated to represent the variance between the groups, divided by the variance within the groups. A large F ratio indicates that there is more variability between the groups caused by the independent variable than there is within each group, referred to as the error term (Pallat, 2005). Therefore, this is an indication of a better predictor model. The $\mathrm{F}$ value of 146.75 indicates that the overall regression model is significant hence it has some explanatory value. This indicates that there is a significant relationship between the predictor variables; facility resource conservation, water recycling and reuse, land management and social sustainability practices and environmental dimension. At 95 percent confidence interval i.e. $\mathrm{P}$-value $(\mathrm{p}=0.00<0.05)$ implies that all the independent variables combined do influence the decisions to environmental dimension.

From Table 3, the variable had no multicollinearity since the VIF were less than 10. Facility Resource Conservation has the most statistically significant coefficient as indicated by a t-ratio of 1.296 and $P$ value (.000). This implies that one unit change in facility resource conservation will change environmental dimension by 0.429 units, water recycling and use is statistically significant as indicated by a $\mathrm{P}$ value of 0.005 hence this implies that one unit change in water recycling and use will change environmental dimension by 0.040 units, land management has a $\mathrm{P}$ value of 0.007 implying that one unit change in land management will change environmental dimension by 0.239 units, and social sustainability practices will change environmental dimension by 0.120 units. Constant equals 0.08 , shows that if the level of predictors are held at constant zero, environmental dimensional would be 0.08 . The standardized coefficients (Beta) are 
Table 2. Analysis of Variance (ANOVA).

\begin{tabular}{ccccccc}
\hline & Model & Sum of Squares & Df & Mean Square & F & Sig. \\
\hline \multirow{3}{*}{1} & Regression & 9.392 & 4 & 2.348 & 146.75 & $0.000^{\mathrm{a}}$ \\
& Residual & 0.537 & 33 & 0.016 & & \\
& Total & 8.929 & 37 & & \\
\hline
\end{tabular}

a. Predictors: (Constant), Facility resource conservation, water recycling and reuse, land management and social sustainability; b. Dependent Variable: Environmental dimension. Source: (Research Data, 2015).

Table 3. Coefficients

\begin{tabular}{ccccccccccccc}
\hline & \multicolumn{2}{c}{$\begin{array}{c}\text { Unstandardized } \\
\text { Coefficients }\end{array}$} & $\begin{array}{c}\text { Standardized } \\
\text { Coefficients }\end{array}$ & & \multicolumn{4}{c}{$\begin{array}{c}\text { 95.0\% Confidence } \\
\text { Interval for B }\end{array}$} & Collinearity Statistics \\
\cline { 2 - 10 } & B & Std. Error & Beta & T & Sig. & $\begin{array}{c}\text { Lower } \\
\text { Bound }\end{array}$ & $\begin{array}{c}\text { Upper } \\
\text { Bound }\end{array}$ & Tolerance & VIF \\
\hline 1 (Constant) & 0.080 & 0.416 & & 0.193 & 0.847 & -0.743 & 0.904 & \\
Facility Resource Conservation & 0.429 & 0.100 & 0.383 & 1.296 & 0.000 & 0.231 & 0.627 & 0.293 & 3.411 \\
Water recycling and use & 0.040 & 0.014 & 0.157 & 2.844 & 0.005 & 0.012 & 0.068 & 0.768 & 1.302 \\
Land management & 0.239 & 0.086 & 0.317 & 2.767 & 0.007 & 0.068 & 0.411 & 0.448 & 2.231 \\
Social sustainability practices & 0.120 & 0.060 & 0.159 & 4.996 & 0.049 & 0.001 & 0.239 & 0.919 & 1.088 \\
\hline
\end{tabular}

a. Dependent Variable: Environmental dimension. Source: Research data, (2015).

what the regression coefficients would be if the model were fitted to standardized data, that is, if from each observation we subtracted the sample mean and then divided by the sample SD.

The multiple linear regression equation becomes:

$$
Y=0.080+0.429 X_{1}+0.040 X_{2}+0.239 X_{3}+0.120 X_{4}
$$

\subsection{Sustainable Supply Chain Practices and Social Performance}

The model summary is presented in Table 4. The model is highly significant ( $\mathrm{p}$ $=0.000$ ) showing that the model is functional. The model has an $\mathrm{R}$ square value of 0.264 indicating that the percentage of the dependent variable variance that is explained by the independent variables is $26.4 \%$. The P-value of 0.000 i.e. less than 0.05 implies that the model of social dimensional is significant at the 5 per cent significance. $\mathrm{R}$ is the correlation coefficient which shows the relationship between the study variables, from the findings shown in the table below there is a strong positive relationship between the study variables as shown by 0.563 . The findings show that Durbin-Watson value is 2.208 hence no autocorrelation in the sample.

The ANOVA from Table 5 shows that the $\mathrm{F}$ value of 50.955 indicates that the overall regression model is significant hence it has some explanatory value. This indicates that there is a significant relationship between the predictor variables i.e. facility resource conservation, water recycling and reuse, land management and social sustainability practices and social dimension. At 95 percent confidence interval i.e. P-value $(p=0.00<0.05)$ implies that all the independent variables combined do influence the decisions to social dimension. 
Table 4. Regression model summary.

\begin{tabular}{ccccccccccc}
\hline \multirow{2}{*}{ Model } & \multirow{2}{*}{$\mathrm{R}$} & \multirow{2}{*}{ R Square } & \multirow{2}{*}{$\begin{array}{c}\text { Adjusted } \\
\text { R Square }\end{array}$} & \multirow{2}{*}{$\begin{array}{c}\text { Std. Error } \\
\text { of the Estimate }\end{array}$} & \multicolumn{5}{c}{ Change Statistics } \\
\cline { 6 - 9 } & & & & & R Square Change & F Change & df1 & df2 & Sig. F Change & Durbin-Watson \\
\hline 1 & $0.563 \mathrm{a}$ & 0.317 & 0.264 & 3.02638 & 0.317 & 5.971 & 9 & 116 & 0.000 & 2.208 \\
\hline
\end{tabular}

a. Predictors: (Constant), Facility resource conservation, water recycling and reuse, land management and social sustainability; b. Dependent Variable: Social dimension. Source: (Research Data, 2015).

Table 5. Analysis of variance (ANOVA).

\begin{tabular}{ccccccc}
\hline \multicolumn{2}{c}{ Model } & Sum of Squares & Df & Mean Square & F & Sig. \\
\hline & Regression & 27.312 & 4 & 6.828 & 50.955 & $0.015^{\mathrm{a}}$ \\
1 & Residual & 4.437 & 33 & 0.134 & & \\
& Total & 31.749 & 37 & & &
\end{tabular}

a. Predictors: (Constant), Facility resource conservation, water recycling and reuse, land management and social sustainability; b. Dependent Variable: Social dimension. Source: (Research Data, 2015).

From Table 6, the variable had no multicollinearity since the VIF were less than 10. All the predictors were significant with $P$ value less than 0.005 . This implies that one unit change in facility resource conservation will change social dimension by 0.294 units, one unit change in water recycling and use will change social dimension by 0.230 units, one unit change in land management will change social dimension by 0.013 units, and social sustainability practices will change social dimension by 0.421 units. Constant equals 0.24 , shows that if the level of predictors are held at constant zero, social dimensional would be 0.24 . The standardized coefficients (Beta) are what the regression coefficients would be if the model were fitted to standardized data, that is, if from each observation we subtracted the sample mean and then divided by the sample SD. The multiple linear regression equation becomes:

$$
Y=0.240+0.294 X_{1}+0.230 X_{2}+0.013 X_{3}+0.421 X_{4}
$$

\subsection{Sustainable Supply Chain Practices and Economic Performance}

The model summary is presented in Table 7. The model has an $\mathrm{R}$ square value of 0.718 indicating that the percentage of the dependent variable variance that is explained by the independent variables is $71.8 \%$. The $\mathrm{P}$-value of 0.000 i.e. less than 0.05 implies that the model of economical dimension is significant at 5 per cent significance. $\mathrm{R}$ is the correlation coefficient which shows the relationship between the study variables. The findings shown in the table below indicate that there is a strong positive relationship between the study variables as shown by 0.847 . The findings show that Durbin-Watson value is 1.981 hence no autocorrelation in the sample.

The ANOVA from Table 8 shows that the F value of 16.025 indicates that the overall regression model is significant hence it has some explanatory value. This indicates that there is a significant relationship between the predictor variables 
Table 6. Coefficients-social dimension.

\begin{tabular}{|c|c|c|c|c|c|c|c|c|c|}
\hline \multirow{2}{*}{ Model } & \multicolumn{2}{|c|}{$\begin{array}{l}\text { Unstandardized } \\
\text { Coefficients }\end{array}$} & \multirow{2}{*}{$\begin{array}{c}\text { Standardized } \\
\text { Coefficients }\end{array}$} & \multirow[b]{2}{*}{$\mathrm{T}$} & \multicolumn{3}{|c|}{$\begin{array}{c}95.0 \% \text { Confidence } \\
\text { Interval for B }\end{array}$} & \multicolumn{2}{|c|}{ Collinearity Statistics } \\
\hline & B & $\begin{array}{l}\text { Std. } \\
\text { Error }\end{array}$ & & & Sig. & $\begin{array}{l}\text { Lower } \\
\text { Bound }\end{array}$ & $\begin{array}{l}\text { Upper } \\
\text { Bound }\end{array}$ & Tolerance & VIF \\
\hline 1 (Constant) & 0.240 & 0.258 & & 0.930 & 0.354 & 11.161 & 2.784 & & \\
\hline Facility resource conservation & 0.294 & 0.077 & 0.297 & 3.798 & $0.000^{*}$ & 0.766 & 0.929 & 0.342 & 2.921 \\
\hline Water recycling and use & 0.230 & 0.070 & 0.188 & 3.290 & $0.043^{*}$ & 0.191 & 1.970 & 0.321 & 3.112 \\
\hline Land management & 0.013 & 0.062 & 0.013 & 0.215 & $0.009^{*}$ & 1.755 & 3.796 & 0.316 & 3.169 \\
\hline Social sustainability practices & 0.421 & 0.077 & 0.406 & 5.445 & $0.000^{*}$ & 0.437 & 0.028 & 0.967 & 1.034 \\
\hline
\end{tabular}

a. Dependent variable: Social dimension. Source: (Research Data, 2015).

Table 7. Regression model summary.

\begin{tabular}{|c|c|c|c|c|c|c|c|c|c|c|}
\hline \multirow[b]{2}{*}{ Model } & \multirow[b]{2}{*}{$\mathrm{R}$} & \multirow[b]{2}{*}{ R Square } & \multirow{2}{*}{$\begin{array}{l}\text { Adjusted } \\
\text { R Square }\end{array}$} & \multirow{2}{*}{$\begin{array}{c}\text { Std. Error } \\
\text { of the Estimate }\end{array}$} & \multicolumn{5}{|c|}{ Change Statistics } & \multirow[b]{2}{*}{ Durbin-Watson } \\
\hline & & & & & $\begin{array}{l}\text { R Square } \\
\text { Change }\end{array}$ & $\begin{array}{c}\mathrm{F} \\
\text { Change }\end{array}$ & df1 & df2 & $\begin{array}{c}\text { Sig. } \\
\text { F Change }\end{array}$ & \\
\hline 1 & $0.847^{\mathrm{a}}$ & 0.718 & 0.699 & 0.669 & 0.718 & 38.490 & 8 & 121 & 0.000 & 1.981 \\
\hline
\end{tabular}

a. Predictors: (Constant), Facility resource conservation, water recycling and reuse, land management and social sustainability; b. Dependent Variable: Economic dimension. Source: (Research Data, 2015).

Table 8. Analysis of variance (ANOVA).

\begin{tabular}{ccccccc}
\hline \multicolumn{2}{c}{ Model } & Sum of Squares & Df & Mean Square & F & Sig. \\
\hline & Regression & 7.565 & 4 & 1.891 & 16.025 & $0.035^{\mathrm{a}}$ \\
1 & Residual & 3.897 & 33 & 0.118 & & \\
& Total & 11.462 & 37 & & &
\end{tabular}

a. Predictors: (Constant), Facility resource conservation, water recycling and reuse, land management and social sustainability; b. Dependent Variable: Economic dimension; Source: (Research Data, 2015).

i.e. facility resource conservation, water recycling and reuse, land management and social sustainability practices and economic dimension. At 95 percent confidence interval i.e., $\mathrm{P}$-value $(\mathrm{p}=0.00<0.05)$ implies that all the independent variables combined do influence the decisions to economic dimension.

From Table 9, the variable has no multicollinearity since the VIF were less than 10. Constant equals 1.34, showing that if the level of predictors is held at constant zero, economic dimension would be 1.34 . Water recycling and use has the most statistically significant coefficient as indicated by a t-ratio of 1.241 and $P$ value 0.002 . This implies that one unit change in Water recycling and use will change economic dimension by 0.121 units, facility resource conservation is statistically significant as indicated by a P value of 0.029 hence this implies that one unit change in facility resource conservation will change economic dimension by 0.294 units, land management has a $\mathrm{P}$ value of 0.031 implying that one unit change in land management will change economic dimension by 0.151 units, 
Table 9. Coefficients.

\begin{tabular}{ccccccccccc}
\hline & \multicolumn{2}{c}{$\begin{array}{c}\text { Unstandardized } \\
\text { Coefficients }\end{array}$} & $\begin{array}{c}\text { Standardized } \\
\text { Coefficients }\end{array}$ & & & \multicolumn{2}{c}{$\begin{array}{c}\text { 95.0\% Confidence } \\
\text { Interval for B }\end{array}$} & Collinearity Statistics \\
\cline { 2 - 9 } & B & Std. Error & Beta & T & Sig. & $\begin{array}{c}\text { Lower } \\
\text { Bound }\end{array}$ & $\begin{array}{c}\text { Upper } \\
\text { Bound }\end{array}$ & Tolerance & VIF \\
\hline 1 (Constant) & 1.34 & 0.76 & & 0.54 & 0.035 & & & & \\
Facility resource conservation & 0.294 & 0.123 & 0.267 & 2.443 & 0.029 & 0.023 & 0.134 & 0.413 & 2.444 \\
Water recycling and use & 0.121 & 0.093 & 0.134 & 1.241 & 0.002 & 0.232 & 0.012 & 0.332 & 2.432 \\
$\quad$ Land management & 0.151 & 0.043 & 0.294 & 3.950 & 0.031 & 0.0134 & 0.056 & 0.883 & 1.123 \\
Social sustainability practices & 0.470 & 0.182 & 0.784 & 2.573 & 0.014 & 0.100 & 0.840 & 0.456 & 3.565 \\
\hline
\end{tabular}

a. Dependent Variable: Economic dimension. Source: Research Data, 2015.

and social sustainability practices will change economic dimension by 0.470 units. The standardized coefficients (Beta) are what the regression coefficients would be if the model were fitted to standardized data, that is, if from each observation we subtracted the sample mean and then divided by the sample SD.

The established multiple linear regression equation becomes:

$$
Y=0.134+0.294 X_{1}+0.121 X_{2}+0.151 X_{3}+0.470 X_{4}
$$

It is evident from the analysis and results presented in this study that majority of horticulture firms in Nairobi Kenya have adopted the three dimensions of TBL. TBL must address the three important dimensions of environmental, social and economic. The firms are progressively using TBL to address the issues of sustainability of horticulture supply chains [11]. "Does implementation of environmental and social sustainability practices for the facility and its major suppliers directly improve firm (environmental, quality and cost) performance? What is the relationship between these sustainability-impacted performance outcomes?" Empirical researchers have found positive relationships between a firm's environmental activities (internally in their operations and externally with their supply chain members) and their economic and environmental performance [2] [20].

\section{Discussion}

The study established that most horticulture firms in Nairobi Kenya have operated for less than 10 years. This is a clear indication that they were established at the time when the TBL concept had already gained momentum and there are no alternatives. Around $45.9 \%$ of the firms have operated for a period between 10 to 20 years which shows that such horticulture firms were facing challenges to fully adopt the TBL concept in the entire supply chains. As noted by the authors, some horticulture firms are undertaking the TBL dimensions i.e. the Environmental, Social and Economic with a lot of concerns. It was established that apart from the Supply Chain Manager and Operations Manager, Compliance Officer also existed in some firms whose core responsibility was to make sure that the 
company fully comply with all environmental and social issues. Majority of the firms have corporate social responsibility manager, environmental manager, environmental board of directors and a well elaborate corporate environmental policy. The study findings have largely agreed with the findings of other researchers in the same area.

\section{Limitations and Further Research}

The authors faced a number of challenges when carrying out the study. Firstly, some of the respondents were not very co-operative either by failing to receive the questionnaires for their responses or completely refusing to give the researcher audience to present his case. A good number of respondents declined to revert back the questionnaires forcing only a response rate of $74 \%$. It is also worth to note that the researcher only used one method of collecting data i.e. by use of questionnaire as a tool. Use of other methods like interviews could have enriched data collection process. There are several opportunities for future research generated by this study. First, the analysis of the researcher is specific to the horticulture sector, which faces a relatively unique set of social and environmental sustainability challenges as well as a rapidly growing consumer base for sustainable products. Primary environmental and social sustainability issues and subsequent performance impacts in other industries will likely differ. Consequently, sustainability research may not easily generalize across industries, and industry-specific sustainability research may yield more practical and clear findings than cross-industry studies. Industry differences also point to the need to integrate case and survey-based research methods to rigorously isolate sustainability practices and expected outcomes specific to industries.

\section{Conclusion}

The study concluded that majority of the horticulture firms are fully aware of the benefits of adopting TBL dimensions. They are therefore making efforts of adopting them fully while others have started implementing part of the environmental and social aspects. As indicated in the study findings, most of the firms which have already embraced the three dimensions have in mind of the relationship between TBL and performance. Most supply chain literature has examined environmental sustainability practices, while little research to expand sustainability considerations to social issues has been done. It was therefore the intent of this study to understand the impacts of adoption of environmental and social sustainability practices on performance outcomes for the firm.

\section{References}

[1] Pullman, M., Maloni, M.J. and Carter, C. (2009) Food for Thought: Social versus Environmental Sustainability Practices.

[2] Roth, A., Tsay, A., Pullman, M. and Grey, J. (2008) Unraveling the Global Food Supply Chain: Strategic Lessons from China and the Pet Food Recalls. Journal of Supply Chain Management, 44, 22-39. 
https://doi.org/10.1111/j.1745-493X.2008.00043.x

[3] Bradsher, K. (2008) The Food Chain, a New, Global Oil Quandary: Costly Fuel Means Costly Calories. New York Times, January 19, 2008.

http://www.nytimes.com

[4] Lovins, A.B., Lovins, L.H. and Hawken, P. (1999) A Road Map for Natural Capitalism. Harvard Business Review, 85, 172-183.

[5] Thomas, A., Francis, M., Elwyn, J. and Davies, A. (2011) Identifying the Characteristics for Achieving Sustainable Manufacturing Companies. Journal of Manufacturing Technology Management, 23, 426-440. https://doi.org/10.1108/17410381211230376

[6] Seuring, S. (2011) Supply Chain Management for Sustainable Products Insights from Research Applying Mixed-Methodologies. Business Strategy and the Environment, 20, 471-484. https://doi.org/10.1002/bse.702

[7] Andersen, M. and Skjoett-Larsen, T. (2009) Corporate Social Responsibility in Global Supply Chains. Supply Chain Management-An International Journal.

[8] Elkington, J. (1998) Partnerships from Cannibals with Forks. The Triple Bottom Line of $21^{\text {st }}$ Century Business. Environmental Quality Management, 6, 37-51. https://doi.org/10.1002/tqem.3310080106

[9] Seuring, S. and Müller, M. (2008) From a Literature Review to a Conceptual Framework for Sustainable Supply Chain Management. Journal of Cleaner Production, 16, 1699-1710. https://doi.org/10.1016/j.jclepro.2008.04.020

[10] Simpson, B.J.K. and Radford, S.K. (2014) Situational Variables and Sustainability in Multi-Attribute Decision-Making. European Journal of Marketing, 48, 1046-1069. https://doi.org/10.1108/EJM-04-2012-0219

[11] Isaksson, R.R., Garvare, R. and Johnson, M. (2015) The Crippled Bottom Line Measuring and Managing Sustainability. International Journal of Productivity and Performance Management, 64, 334-355. https://doi.org/10.1108/IJPPM-09-2014-0139

[12] Foran, B., Lenzen, M., Dey, C. and Bilek, M. (2005) Integrating Sustainable Chain Management with Triple Bottom Line Accounting. Ecological Economics, 52, 143-157. https://doi.org/10.1016/j.ecolecon.2004.06.024

[13] Ashby, A., Leat, M. and Smith, M.H. (2012) Making Connections: A Review of Supply Chain Management and Sustainability Literature. Supply Chain Management: An International Journal.

[14] Skjøtt-Larsen, T., Schary, P.B., Mikkola, J.H. and Kotzab, K. (2007) Managing the Global Supply Chain. 3rd Edition, Copenhagen Business School Press, Copenhagen.

[15] Freeman, R.E., Harrison, J.S., Wicks, A.C., Parmar, B. and de Colle, S. (2010) Stakeholder Theory: The State of the Art. Cambridge University Press, Cambridge. https://doi.org/10.1017/CBO9780511815768

[16] Carter, C.R. and Rogers, D.S. (2008) A Framework of Sustainable Supply Chain Management: Moving toward New Theory. International Journal of Physical Distribution \& Logistics Management, 38, 360-387. https://doi.org/10.1108/09600030810882816

[17] Carter, C.R. and Easton, P.L. (2011) Sustainable Supply Chain Management: Evolution and Future Directions. International Journal of Physical Distribution \& Logistics Management, 41, 46-62. https://doi.org/10.1108/09600031111101420

[18] Elkington, J. (2004) Enter the Triple Bottom Line. In: Henriques. A. and Richardson, J., Eds., The Triple Bottom Line, Does It All Add up? Assessing the Sustainabil- 
ity of Business and CSR, Earths can Publications Ltd., London, 1-16. https://doi.org/10.1108/13598540910941948

[19] Maloni, M.J. and Brown, M.E. (2006) Corporate Social Responsibility in the Supply Chain: An Application in the Food Industry. Journal of Business Ethics, 68, 35-52. https://doi.org/10.1007/s10551-006-9038-0

[20] Rao, P. and Holt, D. (2005) Do Green Supply Chains Lead to Competitiveness and Economic Performance? International Journal of Operations \& Production Management, 25, 898-916. https://doi.org/10.1108/01443570510613956 


\section{Appendix: Research Questionnaire}

This questionnaire is designed to collect data on Sustainability and TBL Performance in Horticultural Sector Supply Chains in Kenya. This is entirely meant for academic purposes. All the information will be treated with confidentiality it deserves.

\section{Section 1: Horticultural Firm Profile}

Q1. 1) Name of the Horticultural firm (Optional)

2) Company ownership:

a) Local [ ]

b) Foreign [ ]

c) Other [ ] Specify

3) What position do you hold in the firm?

a) Supply Chain Manager [ ]

b) Operations Manager [ ]

c) Other [ ] Specify

4) Number of years the firm has been in operation.

a) Less than 10 years [ ]

b) 10 - 20 years [ ]

b) More than 20 years [ ]

5) What is the current number of employees in the firm?

a) Less than 20 [ ]

b) $21-50$ [ ]

c) More than 50 [ ]

6) What range of products does your firm produce?

a) Vegetables [ ]

b) Fruits [ ]

c) Flowers [ ]

d) Others [ ] Specify

7) What is your firm's market?

a) Local Market [ ]

b) Foreign Market [ ]

c) Others [ ] Specify

\section{Section 2: Adoption of TBL Dimensions}

Q2(a): Please indicate with a tick $(\sqrt{ })$ the extent to which your firm has adopted the following TBL practices using a rating scale where $5=$ to a very large extent, $4=$ to a large extent, $3=$ to a moderate extent, $2=$ to a small extent and 1 $=$ not at all.

\begin{tabular}{|c|c|c|c|c|c|c|}
\hline NO & Environmental Dimension & 5 & 4 & 3 & 2 & 1 \\
\hline 1 & The firm has Formal Environmental Management System & & & & & \\
\hline 2 & $\begin{array}{l}\text { The firm has clearly stated its environmental } \\
\text { objectives and action plans }\end{array}$ & & & & & \\
\hline 3 & The company uses pesticides that are not harmful to the environment. & & & & & \\
\hline
\end{tabular}




\section{Continued}

4 The company usually carries out environmental audits.

5 A good percentage of the profit made is used to improve the environment. The firm emphasizes on suppliers who take environmental concerns seriously. The firm demands environmental standards certification from suppliers.

8 The company's packaging materials are bio-degradable.

9 The firm makes use of recycled raw materials.

10 The firm uses products with eco-benefits with an aim of preservation of the environment.

11 The company uses green label as an indicator of environmental friendliness.

12 The company utilizes environmentally friendly cleaning materials throughout the premises (use of chemical free cleaning materials).

\section{Social Dimension}

The company's human resource is ensuring and facilitating worker skill development.

14 The company does not use child labor on the farms.

15 Corporate social responsibility is key to the company.

16 Job satisfaction of workers is the key concern to the company.

17 The company ensures that worker quality of life is attained.

\section{Economic Dimension}

18 The firm uses sustainable sources of raw materials.

19 The company has an active recycling program for materials in all sections.

20 The company uses packaging made of recyclable materials.

21 The firm uses sustainable sources of energy such as solar and wind.

Priority is given to local suppliers especially those in which the firm is operating from.

23 Cost savings, maximization of shareholders' wealth and profit maximization are key concerns to the senior management. The company uses minimum transportation packaging materials for purposes of preserving natural resources. The firm uses minimum packaging materials on the products to preserve the natural resources.

26 There is fair compensation (living wage) to all employees.

27 The firm run and has embraced certified programs.

Q2(b): Please indicate by ticking $(\sqrt{ })$ where appropriate or list where possible. i) A position of corporate social responsibility manager $\quad$ Yes... No... ii) A position of environmental manager $\quad$ Yes... No... iii) An environmental board of director $\quad$ Yes... No... iv) Corporate environmental policy $\quad$ Yes... No...

v) What are some of the social responsibility that the company has engaged itself in. 


\section{Section 3: Triggers/Drivers of Sustainability in Horticulture Sector}

Q3. Using the five point rating scale where $5=$ Very large extent, $4=$ Large extent, $3=$ Moderate extent, $2=$ Small extent and $1=$ Not at all, indicate by ticking $(\sqrt{ })$ in the appropriate box the extent to which the triggers listed below have influenced sustainability in your firm.

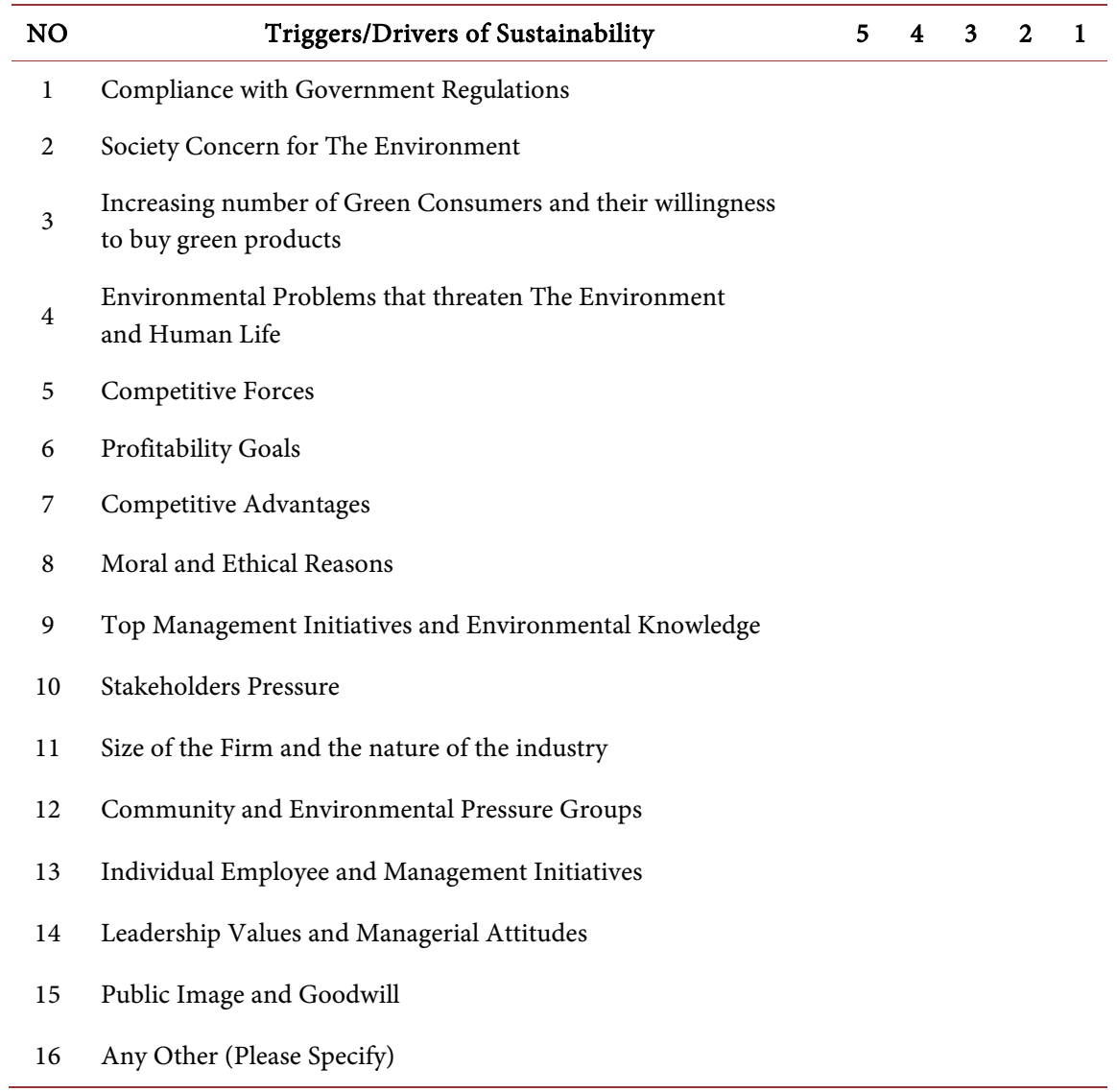

\section{Section 4: Relationship between SSCM Practices and Performance}

Q4. Using the five point rating scale where $5=$ Very large extent, $4=$ Large extent, $3=$ Moderate extent, $2=$ Small extent and $1=$ Not at all, indicate by ticking $(\sqrt{ })$ in the appropriate box the relationship between SSCM Practices and Performance.

\begin{tabular}{|c|c|c|c|c|c|c|}
\hline NO & SSCM Practices and Performance Outcomes & 5 & 4 & 3 & 2 & 1 \\
\hline 1 & $\begin{array}{l}\text { Environmental performance improves with increased adoption } \\
\text { of facility resource conservation, waste recycling and reuse, } \\
\text { and land management environmental sustainability practices. }\end{array}$ & & & & & \\
\hline 2 & $\begin{array}{l}\text { Quality performance improves with increased adoption of } \\
\text { facility resource conservation, waste recycling and reuse, } \\
\text { and land management environmental sustainability practices. }\end{array}$ & & & & & \\
\hline 3 & $\begin{array}{l}\text { Cost performance improves with increased adoption of } \\
\text { facility resource conservation, waste recycling and reuse, } \\
\text { and land management environmental sustainability practices. }\end{array}$ & & & & & \\
\hline
\end{tabular}




\section{Continued}

4 Environmental performance improves with increased adoption of social sustainability practices.

- Quality performance improves with increased adoption of social sustainability practices.

6 Cost performance improves with increased adoption of social sustainability practices.

7 Quality performance improves with environmental performance.

8 Cost performance improves with environmental performance.

9 Cost performance improves with quality performance. 